\title{
In The Face of Gentrification: A Case Study of Social Capital in supporting Community Efforts to Form A Collective Action
}

\author{
Azka Nur Medha ${ }^{1}$, Putu Gde Ariastita ${ }^{1}$
}

\begin{abstract}
Gentrification is believed to be an urban phenomenon that has a negative impact on neighborhood society. Therefore, the neighborhood community becomes an important study object in order to understand the process of gentrification itself. This study observes the community in Medokan Semampir community group, Surabaya, that raised a case study in which they made collective action to face gentrification. Collective action can be viewed as a solution in order to facilitate the common interests of a gentrified community. The aim of this paper is to explain the collective action process in the context of social capital, and how communities can keep the capital as collective assets to prevent gentrification processes anguish its members.
\end{abstract}

Keywords - Collective action, collective assets, gentrification, social capital.

\section{INTRODUCTION}

$F_{\mathrm{i}}^{\mathrm{o}}$ or decades academics of urban studies have been identifying and exploring an urban phenomenon called gentrification. Gentrification is the process of urban renewal that involves the betterment of a neighborhood and has commonly included the displacement of a group of people by other with greater resource [1]-[3]. Gentrification is often characterized by a rapid increase in property values, as it caused the origin community becomes vulnerable [4],[5]. Therefore, it is obvious that gentrification leads to negative impact to the community that they might move out from their neighborhood.

Gentrification is an urban phenomenon that arises when it's viewed from the standpoint of social aspects, which cannot be solved by the planning approach with only concerns with the physical aspect. Nevertheless, gentrification has not been widely discussed in most of the city in Indonesia although the impact indirectly been perceived by the society who had experienced it. From the physical aspect point of view, gentrification might not seem as a problem, as the negative impact is actually accepted by the community only. Moreover, the consequences of such planning approach is there's no kind of action that can offer the solution to the society to resolve a circumstance which gentrification might have a chance or even already occur in particular area.

Meanwhile, planning theory keeps developed over time until now. The previous study in urban major leads to a conclusion of what is the best solution that could be accommodated by planner in their actions. Solutions in dealing with the negative impacts of gentrification refer to

\footnotetext{
${ }^{1}$ Azka Nur Medha, Putu Gde Ariastita are with Department of Urban and Regional Planning, Faculty of Architcture, Design and Planning, Institut Teknologi Sepuluh Nopember (ITS), Kampus ITS Sukolilo, Surabaya 60111, Indonesia. E-mail: azkanurmedha@gmail.com; ariastita@urplan.its.ac.id;
}

Myung [6] is; 1) By making public policy in order to control land prices, and 2) By involving community-based organization to mobilized the possible victims. The main aims of community organizing is to create a capacity of the organization to have a capability in order to represent it's common interests, then influence the stakeholders which involved in gentrification process. To be able to do that, the community needs to create their social capacity first, and the community-based organization has an important role in creating those capacities. Therefore, the role of community organizing needs to be understood as one of the solutions to support the society who were facing gentrification.

The most relevant issue for analyzing the dynamics of the community-based organization is a conception called the collective action, as it contributes of the commencement of the organization itself [7]. Community organizations are highly dependent on how collective action develop, and how the society organizes them institutionally. Vanni, F suggest that collective action can be facilitated informally (without organizing). Furthermore, Olson states that community organizing usually shows a great level of common interest in the community, thus it will encouraging collective action that has significance for the community [8]. Therefore, many pieces of literature in which discussed collective action in community organizing usually includes social capital aspects which give an enormous effect that determine whether the organization would fail or succeed. Social capital is defined in terms of networks, norms, and manners that enable agents and institutions to be more effective in realizing the common goals [9]. In the context of community organizations, the focus of social capital is on a group scale, and the emphasis stand on how certain groups form and maintain their social capital as collective assets and how these collective assets can improve the wellbeing of their members [10]

This research located in Medokan Semampir district, Surabaya. Medokan Semampir is now experiencing a 
gentrification signed by rapid land prices since MERR (Middle East Ring Road) was built in 2008. MERR has been successfully transforming its surrounding area into a high-value area, that makes the area including Medokan Semampir district is a very promising for any kind of property investment. The issue arises when the community of Medokan Semampir engage a collective action which aims to associate the community members to the investor, as they want to sell their land property collectively. Apparently, the fact that community in other terms would be 'displaced' if they reach their goals, it is easy to recognize that gentrification in Medokan Semampir is undeniable. One might oppose this type of tragedy is even worse to overall gentrification process but the focus of this paper is to find a social capital factors that support the excogitation of community collective action. Social capital is vitally important in the ongoing social process which makes community enable to improve the situation of gentrification process to something that makes them less vulnerable, by creating bargaining value of their land prices. Furthermore, this study also gives depictions about how social capital lasts as community asset along with the collective action process.

\section{METHOD}

Case study research with a qualitative approach was conducted in this study. Case study research defines that case study research method is appropriate when it applied to analyze the research object with the special case [10], whereas this research demanded to be able explaining comprehensively the uniqueness of society in Medokan Semampir who response the gentrification process with community collective action. In order to formulate what are the social capital factors that community of Medokan Semampir has in implementing the collective action to face gentrification, first the exhaustive of full description about the social process which accompanies the whole process must be well understood. This study uses an in-depth interview method to collect all pieces of information from the key informants through snowball sampling, and the first conducted interview began with the community leader. That first informant who selected was based on subjective judgment from the researcher. Then, snowball sampling keeps continuing from another additional informant suggest by informant before until the research question was completely answered [11]. In total, there were seven interviews and all of it were tape-recorded, which then the voice data were transformed to text transcript. The analysis method that used in this study is through content analysis. In these step, the social capital factors successfully identified along with its role to support the collective action

\section{RESULT AND ANALYSIS}

A. Depiction of rapid development in Medokan Semampir district compared to official spatial plan

Medokan Semampir district located right beside of MERR road, and during its development, it turns the surrounding area includes Medokan Semampir district encountering significant land use change. A previous study by Surabaya planning agency in 2009 states that the land traced by MERR road which was originally supposed to be an area for settlement and agricultural only now has deviated. Before the existence of MERR road, land use that occupied by settlement area approximately $126.278,32 \mathrm{~m}^{2}$, while the agricultural land covers $654.100,19 \mathrm{~m}^{2}$ which spread in the various area. However, in 2014, the land use that dominated by agriculture area before changed into a road network system, commercial and public facilities use. This sudden transformation supports by a location factors wherein since MERR road was built the surrounding area becomes more strategic than before. MERR road provides society with a very easy access to urban mobility. Those changes happened in Medokan Semampir district as well. The illustration of Medokan Semampir area transformation can be seen in the picture below.

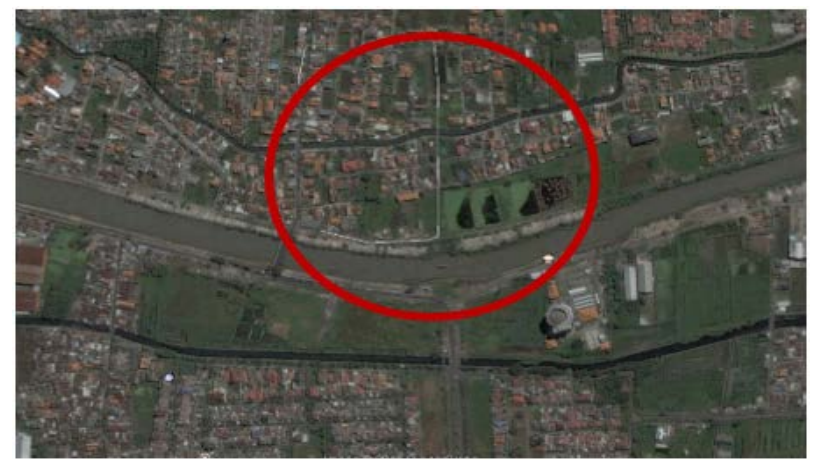

Figure 1. Medokan Semampir land area in 2002

MERR road has not been built. The land of Medokan Semampir occupied by settlements in general.

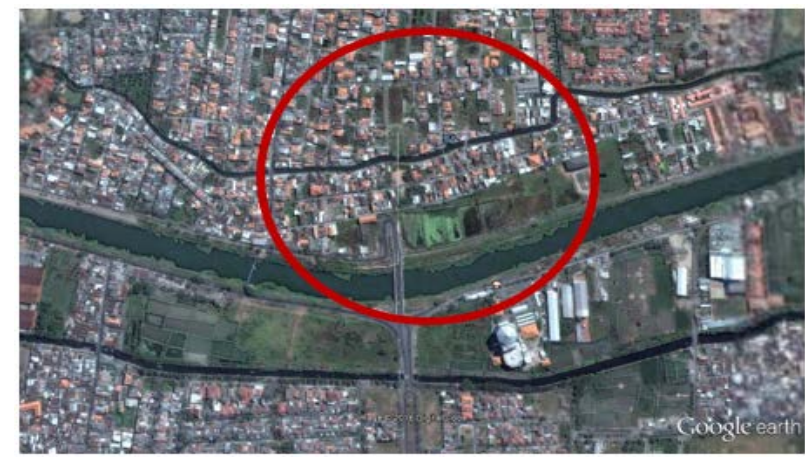

Figure 2. Medokan Semampir land area in 2009

MERR road construction has been processed. At that time, MERR road was connecting separated land by the river. Settlements began to concentrates near the road

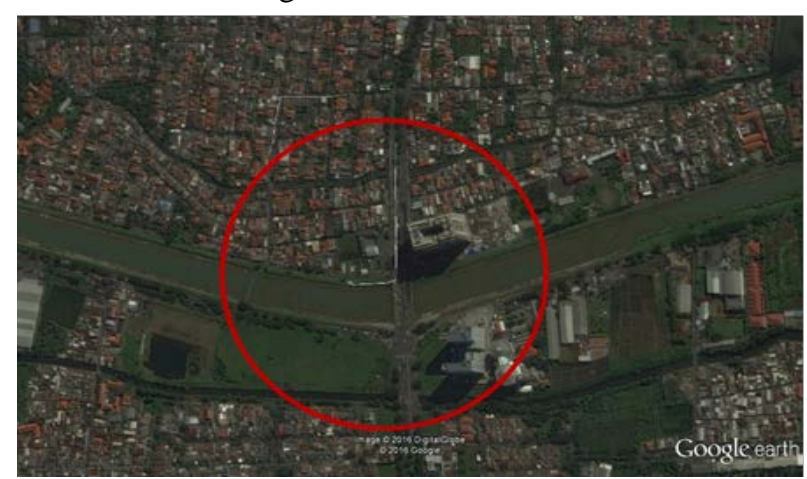

Figure 3. Medokan Semampir land area in 2014 
MERR road has been operating for approximately two years. During that time, there were already two apartments built right in front of the study area

The rapid change in developing area after the establishment of MERR road also caused another issue, which changed the spatial pattern of local planning. This fact actually contributes to gentrification process. The spatial pattern plan in the study area can be seen in Fig.4. From the figure which made by official planning agency in Surabaya we can conclude that perhaps in the future that plan will be deviated much more, as the study area of Medokan Semampir district were schemed to be sold to the investor. If the scheme succeeds in the future, then there is a big opportunity that the investor will demolish the existing residential and built up plenty of commercial building. The supposition of what might happen after the community of Medokan Semampir reach their goals implied that the biggest profit earned by the shareholders who invest in development field only, not for people. Specifically for the community in Medokan Semampir, for instance, is officially got the title of gentrified community. But that's probably just a notion from academician point of view. For Medokan Semampir community, these circumstances, in fact, open up an opportunity to improve their living standard by an economic profit which they can get from the investor after the transaction is done. As one of the informant stated that the vision of Medokan Semampir community is: "Improving the community quality of living standard by selling their property asset to the investor globally". From the community perspective, that is the best way in order to response gentrification. They choose to move out from their settlement area with a bargaining value rather than waiting until the situation in Medokan Semampir district is beyond of their comfort zone accompaniment with the continuous growth of commercial activity.

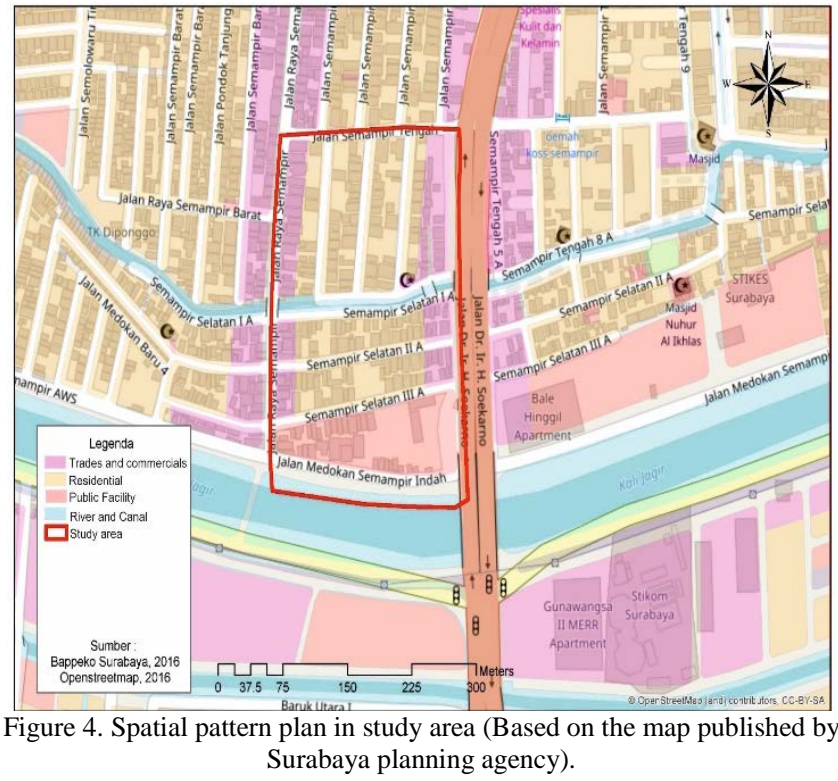

\section{B. Social capital factors in supporting community collective action}

This research raises the context of social capital for a purpose. Social capital in this study claims to recognize social processes as well, so the relationship which built in institutionalizing the collective response of society in facing gentrification by the establishment of community-based organization can be well described. The emphasis that takes on what is the social capital factors that community has specifically aimed to explore how this capital can support the community in achieving collective goals for their common interest. The analysis which conducted in this study found that social capital in a community who currently experiencing gentrification is critically important because it affects the patterns of community relations within its member. Another finding also suggests that community social capital character is dynamic, framed in accordance with the gentrification situation progress that accompanies their social life.

This section will discuss the social capital factors which community have based on their dimensions; cognitive and structural form. First, the discussion will put forward about what is the cognitive and structural dimension and what the connection between them. The cognitive dimension is more subjective, a specifically just mental impulse that is bound by social norms. Meanwhile, the structural dimension is more procedural and binding directly with the process of collective action undertaken by the Medokan Semampir community. However, both cognitive and structural dimension have an important role in community organizing that manifested through collective action.

Cognitive dimension in this study defined as the capital which not directly related to the community organizing performance, but still play a role in the collective action. Indeed, that social capital in cognitive dimension is difficult to measure. Therefore, this study observes the cognitive dimension based on respondents verification on a particular question regarding the subject. The social capital in cognitive dimension which found in the community through this study is:

- Strong social bond within the community

The social bond within the community represents how networking conducted by the community among its members. The social bond in organizing process is notable because it becomes the embodiment of community social capital in order to interact with the actors which involved in organizing system. The closer the relationship between community members, the stronger of social capital they have. This networking pattern of relationships in social capital belongs to the cognitive form, and although it does not directly affect the performance of community organizations, these cognitive forms support structural mechanisms of action. Regarding that, the community of Medokan Semampir district indicates that they already interact with each other cohesively. They also have a strong adherence in which it becomes a capital in the social aspect in order to mobilize community members to perform the collective action, emotionally. Furthermore, they did not feel any burden to executing those action especially in responding to gentrification. In addition, their living routine constantly accompanied by a familiarity that reflects the existence of social bonds in it. 
- High trust among community members

Trust is a positive thought toward others with the expectation that others will reciprocate the same. Community organizing in Medokan Semampir is actually motivated by public trust in managing collective actions that represent the common interests of community members. Trust capital offers a social transformation that enhances people's capacity to encourage people to take collective action in harmony with the values which believed is the best for them.

\section{- Tolerance between social castes}

Tolerance between social castes capital leads the community to able to formulate shared ideas. Although societies have diversity in the economic background, the stimulant from the gentrification situation raises the tolerance of a high social caste to the lower social caste. Tolerance in the community showed, for instance, when some members with adequate economic status already feel comfortable with their settlement and knowing that there are other members who see an opportunity from the escalation of land prices and intend to sell for the sake of their prosperity, they negotiates and finally agreeing to sell the land together. That kind of tolerance has been done to keep up community harmony by making a resolution for the sake of all community members welfare.

- Strong attachment to social norms

Norms in social capital is defined as mutual which believed to be a tool for assessing one's attitude whether it is acceptable or not. Medokan Semampir community was still bound by social norms which maintain the social rules, thus allowing other social capital to emerged in the context of taking collective action to face gentrification.

Moving on to the structural dimension, this dimension refers to social capital in which directly related to community organization performance. The social capital in structural dimension which found in the community through this study is:

- Information exchange among community members

Information exchange among community members becomes the main social capital owned by the community. The strong social bond has actually supported this capital and creates a possibility that any kind of information is disseminated to all members of the community. The information in this context refers to something that related to regional development, specifically in Medokan Semampir district area. This capital helps the community to defines what issues encountering them that caused by MERR road construction.

- Up-to-date to development plans in the surrounding area

In a study that raised the gentrification phenomenon in social capital context, the community must be up-to-date to development plans. The reason for that is it would be impossible for the community to their area position while gentrification still in undergoing process. This capital helps the community to identify how significant their settlement area have been changes as. Apparently, this capital makes Medokan Semampir community becomes stronger.
- Decision-making process

Decision-making process shows the community effort to maintain the polity. Social capital in the decisionmaking process confirms that there is a system within the community organization to determine what decisions the community must take to achieve its objectives.

- The formulation of community vision

For gentrified community, the community vision is fundamental. The action that will execute by the organization is preceded by the vision of the community. Through a vision that has been formulated, the gentrified community can determine what kind of changes they want to perform while they dealing with gentrification process. Community vision can also reinforce their hope for something that community expected to happen in the future. Therefore, community vision is a form of social capital which can bring the community to a choice that they consider to be more prosperous to its members. Medokan Semampir community already has the vision that agreed by all the members. That vision is to sell their property asset to the investor globally.

- Negotiations for perceptual equations

One of the main obstacles faced by community organizations is the agreement on the selling price bargaining value of their asset which they offered to investors. However, the community makes some effort in which they conducted negotiations for perceptual equations. This capital also implies committee willingness to negotiate in order to reach the best decision.

- Strong believes to promised goal made by community

Another important social capital factor in this case study is how communities can trust for what they want to achieve can succeed. To create community capacity in performing the community organization requires social capital that has a strong belief on their own actions. The community of Medokan Semampir also have this kind of capital and shows a positive result. Community members actually believe that one day they can succeed the program. They prove it with always monitoring of the information and progress regarding the community action. This implies that community having a high expectations about their action goals.

From the explaination from each social capital based on their dimension, something that has to be keep in mind is social capital in cognitive form is an existing capital in the society which forms naturally along with their daily life routine in the neighborhood, even before gentrification takes place in Medokan Semampir. Researchers conclude that cognitive capital is a mediator between unrefined idea, to be a negotiated matter until it agreed to be an action that represents common interest. Through that process, a structural capital began to form as the community needs procedural rules to execute their shared act in order to thrive their interest. Therefore, even the cognitive dimension doesn't have a direct function to the implementation of collective action, cognitive dimension is the initial form of social capital manifestation that leads the community to engage a stronger capital in structural form when they begins to perform a collective action. 
TABLE 3. COGNITIVE AND STRUCTURAL FORMS OF SOCIAL CAPITAL IN MEDOKAN SEMAMPIR COMMUNITY.

\begin{tabular}{ll}
\hline \hline \multicolumn{1}{c}{ Cognitive } & \multicolumn{1}{c}{ Structural } \\
- Strong social bond & - Information exchange among \\
within the community & community members \\
- High trust among & - Up-to-date to development plans in \\
community members & the surrounding area \\
- Tolerance between & - Decision-making process \\
social castes & - The formulation of community \\
- Strong attachment to & vision \\
social norms & - Negotiations for perceptual \\
& equations \\
& - Strong believes to promised goal \\
& made by community \\
\hline \hline
\end{tabular}

C. The construction process of the community collective action which supported by social capital

When entering the analysis process in addition to finding social capital factors in the community, evidently, the various perspectives from respondents can also be coupled in order to construct a series of collective action occurrence that supported by social capital. In other words, the construct which will be depicted by the researcher is a conclusion from the researcher of what process in which collective action begins to occur in the presence of cognitive capital first. As explained in the previous chapter, there are four cognitive social capital in society that supported other social capital that are in structural form. The explanation in the preceding chapter has basically been sorted based on the order of the social capital construct which community formed as the occurence of collective action process. The illustration of the construction process of comunity collective action which supported by social capital can be seen in figure 5 .

In figure 5, We can see a sequence of how social capital in the community can be formed in order to deal with gentrification. Nonetheless, The social capital which will be discussed is divided into cognitive and structural forms. The explaination of the illustration in figure 5 are as follows:

Imprimis, take a look at the section of cognitive form of social capital as the prior of capital which started the whole process of collective action that supported by the social capital. Here are the explication:

- Social capital in the cognitive dimension acts as a capital that encourages the creation of structural capital. Capital in the form of attachment to social norms, tolerance between social castes, strong social bonds in the community, and high trust between members is a longitudinal long-term capital, meaning that it continues to accompany the processes thereafter.

- In the social capital of cognitive "attachment to the social norm" and "tolerance between social castes", social capital is still running during the process of organizing takes place without degrading quality.

- On the other hand, the execution of this communitybased organization leads to a consequence of the dissolution in the quality of cognitive social capital. This causes social cohesiveness to worsen, resulting in reduced community capacity. This shows that gentrification, a threat that raises the difficulty of maintaining social capital. It occurs in social capital "Social bond" and "Trust". One of respondent acknowledging that collective action oriented to economic benefits from the sale of their property agreed by the community eventually cause a disturbance of the social cohesiveness within community members because of an issue which came from stimulation of land prices that should be agreed on upon by all members. Same thing also happened in “Trust” capital.

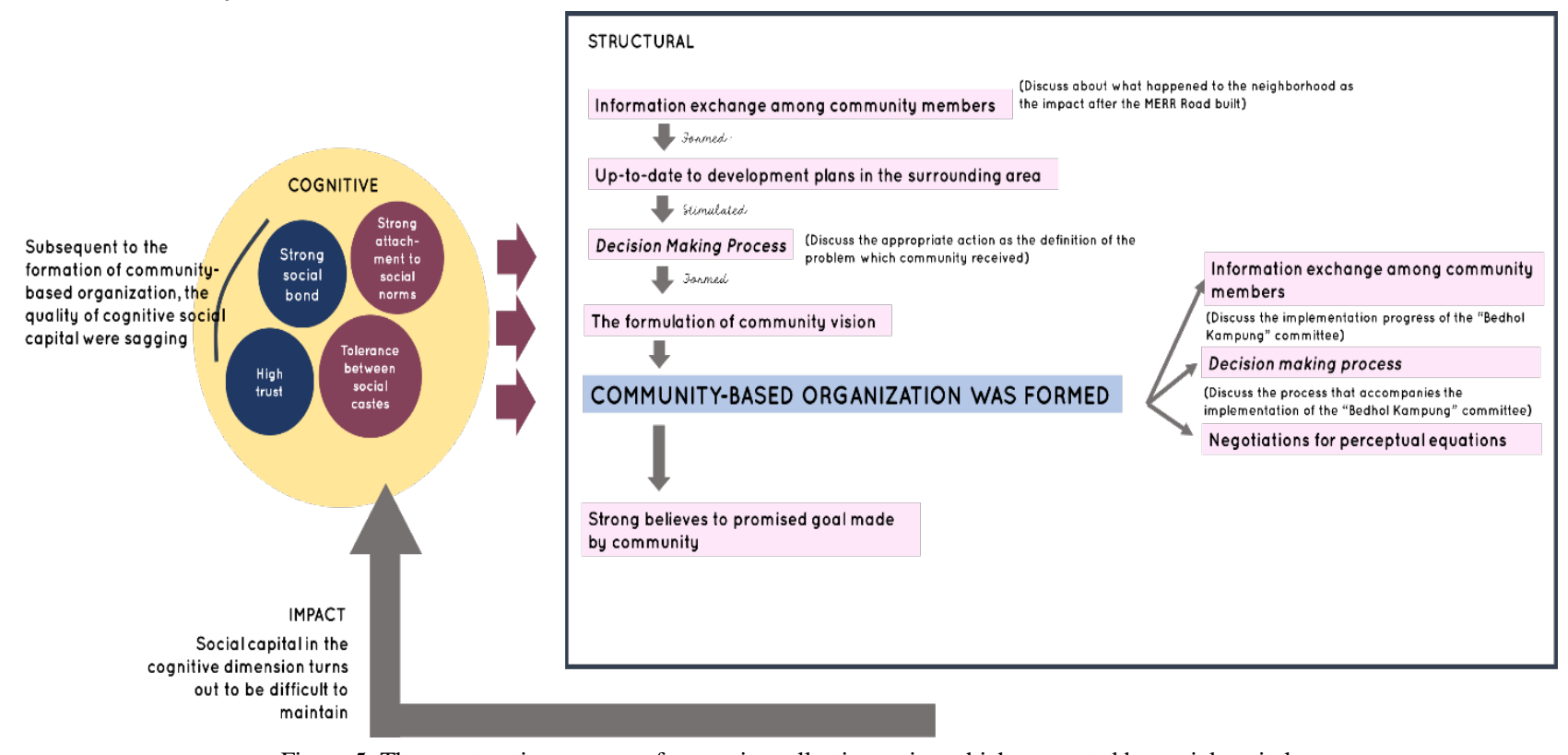

Figure 5. The construction process of comunity collective action which supported by social capital

Secondly, take a look at the section of structural form of social capital. The capital in this form basically begins to emerged after the formation of cognitive capital, and have a direct connection to the performance of community collective action. Here are the explication: 
- The first social capital in the structural dimension is "Information exchange between members". Researchers take a portrait that in the case of gentrified community in Medokan Semampir, information exchange has a very important role to initiate collective action. Information exchange helps people in:

1. People become aware of common problems, and together seek solutions.

2. Involve the community in defining shared ideals and what actions should be taken to achieve them

3. Keep the discussion process going, so that community members remain strongly bound in social relationships

In the prior phase to the community organizations formation, the discussion of information that is transferred to members is about development issues in the area around the Medokan Semampir neighborhood. But in the phase after the formation of community organization, information discussions turned into the development of "Bedhol Kampung" program whose actions are being implemented by the committee. The tools which used for information exchange when community organizations have been formed is a formal meeting/ scheduled meetings, and informal meetings that can occur at any time on the daily events of society.

- As an implication of social capital "Information exchange between members", other social capital has been built, which "Up-to-date community of development plan" in the area around its neighborhood. This capital becomes an important capital for specific communities facing gentrification. Through this capital, the community knows the position of their region in the spatial context. In this case, the position is translated by the community by determining the bargaining position of the investor.

- The subsequent social capital, "Decision-making process" is an emerging social capital driven because people have been able to understand the problem they are facing, which is supported by two previous social capital factors. Decision-making process is a capital that directs society at a more serious stage in the process of organizing the community. This social capital became the beginning of the origin of the idea to form the Committee of Bedhol Kampung.

- The next capital is the capital where the community can already formulate the "Vision of the community". A vision is a valuable form of resistance for the gentrified community. Passing through their self-defined vision, the community can determine their future without having to go through the displacement process, which is a detrimental process for the gentrified community.

- The next process in the construct is the process when a community-based organization is formed, is when the community has passed the exploiting stage of "Bedhol Kampung" Committee. At this stage, the community organizing system has begun to market its land to investors. Social capital at this stage is "negotiation for perceptual equations". This social capital is the capital that aims to keep the collective action that the community chooses together, but only implemented by the committee only. In addition, social capital "Information exchange among members" is also carried out by the community to keep track of the progress of information.

- The last capital that forms a construct of a collective process is capital where the Community "believes in the expected/promised decision". This capital is also a capital that aims to maintain the collective action. This capital needs to be owned by all members of the community as a commitment that they want to produce a collective action.

\section{CONCLUSION}

The study of a social capital factor in the community that takes a case study of Medokan Semampir district basically resulting a conclusion that gentrified community has fulfilled the social capital needed by them in order to face gentrification. In this case study, the social capital owned by the Medokan Semampir community make them a resistant community due to negative impacts of the construction of the MERR Road, the transformation process in the area, and finally to gentrification phenomenon. Social capital leads them to a mutually initiated movement, known in social science studies as a collective action. In order to perform a collective action, the gentrified community in Medokan Semampir district is supported by their social capital asset, which includes both cognitive and structural forms.

However, the actions which chosen by the community as they concern of negative effects of gentrification might harm them by creating a bargaining power to the investor, in the gentrification point of view is an act that actually facilitates the gentrification process itself. Because if community finally reaches their goal, the community will experience the displacement process or the "Expulsion" process due to the pressure of area changing into upgraded areas. However, if we view it from the perspective of social approach, then these social phenomena is actually fine. The reason for that is because the actions they made is a choice of actions that will bring a prosperity for its members. In this case, community resilience is actually being formed. Resilience is shaped because of community awareness, that they can take advantage from the circumstances of gentrification process to gain from the increased value of their property.

\section{ACKNOWLEDGEMENT}

I would like to thank Mr. Putu Gde Ariastita of the Department of Urban and Regional Planning, Sepuluh Nopember Institute of Technology for his invaluable criticism.

\section{REFERENCES}

[1] J. López de Obeso, "Urban Renewal and Controlled Gentrification,” Architectural Association School of Architecture, 2003.

[2] F. Lance, “Future of Fair Housing,” 2008.

[3] R. Atkinson, "Does gentrification help or harm urban 
neighbourhoods?: An assessment of the evidence-base in the context of the new urban agenda (CNR paper 5)," ESRC Cent. Neighb. Res., 2002.

[4] R. Glass, London : Aspects of Change. London: MacGibbon \& Kee, 1964.

[5] N. Smith, The New Urban Frontier. New York: Routledge, 1996.

[6] M.-J. Bang, "Understanding Centrification: The Role and Abilities of Community Based Organization in Changing Neighborhoods, A Case Study of Post-Katrina New Orleans,” The University of Texas at Arlington, 2010.
[7] F. Vanni, "The Role of Collective Action," in Agriculture and Public Goods, Dordrecht: Springer Netherlands, 2014, pp. 21-37.

[8] M. Olson, The Logic of Collective Action. Cambridge, Massachusetts: Hardvard University Press, 1965.

[9] A. Masik, "Hubungan Modal Sosial dan Perencanaan," J. Perenc. Wil. dan Kota, vol. 16, no. 3, pp. 1-23, 2005.

[10] N. Lin, Social capital : a theory of social structure and action. New York: Cambridge University Press, 2001.

[11] B. Bungin, Analisis data penelitian kualitatif. Jakarta: PT RajaGrafindo Persada, 2007. 